\title{
Parthenocarpic Cucumber Cultivar Evaluation in High-tunnel Production
}

\author{
Wenjing Guan ${ }^{1}$, Elizabeth T. Maynard ${ }^{1}$, Bronwyn Aly $^{2}$, \\ Julie Zakes ${ }^{2}$, Daniel S. Egel ${ }^{3}$, and Laura L. Ingwell ${ }^{4}$
}

AdDitIONAL INDEX WORDs. Cucumis sativus, disease resistance, hydroponics, marketability, powdery mildew, two-spotted spider mite

Summary. Fresh-consumed parthenocarpic cucumbers (Cucumis sativus) are a popular and high-value crop sold in local food markets. The parthenocarpic plant characteristics and climbing growth habit make cucumbers an ideal crop for hightunnel production. Major types of parthenocarpic cucumbers include Beit alpha and mini, Dutch greenhouse, American slicer, and Japanese. Information regarding yield performance, plant growth, and disease resistance of the four types grown in high-tunnel conditions is limited. In this study, 16 parthenocarpic cucumber cultivars from the four major types were evaluated in high tunnels at three locations in Indiana and Illinois during Spring 2018. Plants were pruned to a single stem that was supported on a string. At all locations, the cultivars that had the most total yields were Beit alpha and mini, although their total yields were not always significantly higher than that of all the others. However, Beit alpha and mini cucumbers had high percentages of unmarketable fruit, mainly because of insect feeding damage and mechanical injuries on the skins that led to scarred fruit. Dutch greenhouse cultivars had relatively lower marketable yields at two of the three locations where there was a high percentage of misshaped fruit. 'Tasty Green' Japanese cucumber consistently had the lowest yields at all three locations. This cultivar also produced the most side shoot growth and, therefore, more pruning waste. The Japanese types 'Tasty Jade' and 'Taurus' had yields comparable to those of other cultivars, and they were more tolerant to two-spotted spider mites (Tetranychus urticae). However, 'Tasty Jade' was the cultivar most susceptible to powdery mildew (Podosphaera xanthii and Golovinomyces cichoracearum). 'Corinto' American slicer cucumber had relatively high yields at two of the three locations. This cultivar also had the highest percentage of marketable fruit. Information provided in the study is readily useful for growers using high tunnels when selecting parthenocarpic cucumber cultivars. It is also valuable for seed companies wishing to breed new cultivars adaptive for high-tunnel production.

$\mathrm{D}$ uring the past 20 years, high tunnels have become increasingly popular as a valuable tool for small farmers supplying local food markets. In the midwestern United States to date, high tunnels have been primarily used to extend the growing season for tomato (Solanum lycopersicum), winter-grown leafy greens, and, to a lesser extent, other vegetables (Knewtson, et al., 2010). Because tomato provides excellent returns (Nennich and Wold-Burkness, 2012), growers are compelled to grow this crop every year. However, continuously growing this single crop is detrimental to soil health and increases disease and pest problems. Therefore, there is an increasing need to identify alternative crops and provide cultivar recommendations for profitable production of those crop in high tunnels.

High tunnels are plastic-covered structures that provide crops with intermediate environmental control. They increase heat units and block rain, snow, and strong winds. High humidity, low wetness, and a wide range of day and night temperature differences characterize high-tunnel microclimate conditions. Although high tunnels may be considered analogous to greenhouses, environmental conditions in high tunnels are distinctly different from those in greenhouses that are equipped with supplemental lighting, heating, and cooling systems. High-tunnel growers are forced to open the sides and end walls of the structure in the summer to prevent extremely high temperatures inside the structure. Without insect netting, opening the sides and end walls creates an open environment that allows access to insects (Ingwell et al., 2016). Because high-tunnel conditions are much different from those in open fields as well as in greenhouses, suitable cultivars commonly used in those production systems do not always perform well in high tunnels (Wallace et al., 2012).

Fresh-consumed parthenocarpic cucumbers are a popular and highvalue crop sold in local food markets. The plants set fruit without pollination. Their climbing habit is conducive to trellising, which maximizes the use of vertical spaces, making parthenocarpic cucumber an ideal crop for high-tunnel production. Worldwide, parthenocarpic cucumber ranks third on the list of the most important high-tunnel crops, following tomato and pepper (Capsicum annuum) (Lamont, 2009).

Major types of fresh-consumed parthenocarpic cucumbers include Beit alpha, Dutch greenhouse, American slicer, and oriental (Shetty and Wehner, 1998). Fruit characteristics including size, length:diameter ratio, skin color, appearance, and skin thickness vary among the four major types of parthenocarpic cucumbers (Reid, 2015). Consumer preferences and demand for parthenocarpic cucumbers may vary geographically within the United States as well as among various ethnic groups (Tatlioglu, 1993).

Dutch greenhouse cucumbers are exclusively cultivated in greenhouses.

\begin{tabular}{llll}
\hline $\begin{array}{l}\text { Units } \\
\begin{array}{l}\text { To convert U.S. to SI, } \\
\text { multiply by }\end{array}\end{array}$ & U.S. unit & SI unit & $\begin{array}{l}\text { To convert SI to U.S., } \\
\text { multiply by }\end{array}$ \\
\hline 0.3048 & $\mathrm{ft}$ & $\mathrm{m}$ & 3.2808 \\
0.0929 & $\mathrm{ft}^{2}$ & $\mathrm{~m}^{2}$ & 10.7639 \\
0.0283 & $\mathrm{ft}^{3}$ & $\mathrm{~m}^{3}$ & 35.3147 \\
3.7854 & $\mathrm{gal}$ & $\mathrm{L}$ & 0.2642 \\
2.54 & inch(es) & $\mathrm{cm}$ & 0.3937 \\
0.4536 & $\mathrm{lb}$ & $\mathrm{kg}$ & 2.2046 \\
1.1209 & $\mathrm{lb} / \mathrm{acre}$ & $\mathrm{kg} \cdot \mathrm{ha}^{-1}$ & 0.8922 \\
0.1198 & $\mathrm{lb} / \mathrm{gal}$ & $\mathrm{kg} \cdot \mathrm{L}^{-1}$ & 8.3454 \\
1 & $\mathrm{mmho} / \mathrm{cm}$ & $\mathrm{mS} \cdot \mathrm{cm}^{-1}$ & 1 \\
28.3495 & $\mathrm{oz}$ & $\mathrm{g}$ & 0.0353 \\
$\left({ }^{\circ} \mathrm{F}-32\right) \div 1.8$ & ${ }^{\circ} \mathrm{F}$ & ${ }^{\circ} \mathrm{C}$ & $\left({ }^{\circ} \mathrm{C} \times 1.8\right)+32$ \\
& & &
\end{tabular}


Fruit are more than 11 inches long, slender, and have longitudinal ridges. They have thin skin that requires fruit to be individually wrapped to prevent water loss. Beit alpha cucumbers were originally bred for open-field production in Israel (Davidi, 2009); however, many modern Beit alpha cultivars are grown in greenhouses. The fruit are harvested at a length $\approx 5$ to 7 inches, and they have smooth, light green skin. They set multiple fruit on each node and grow well under high (86 to $104{ }^{\circ} \mathrm{F}$ ) and low $\left(50\right.$ to $59^{\circ} \mathrm{F}$ ) temperatures (Cantliffe et al., 2004). Mini cucumbers developed by Dutch seed companies share many fruit characteristics with the Beit alpha cucumbers. They are also grown in greenhouses worldwide; therefore, the two types are discussed together in this work. American slicer cucumbers have thick, dark green skin. They are bred to have good shipping and long shelf-life capabilities. Typically, they are $\approx 6$ to 9 inches long (Shetty and Wehner, 1998; Tatlioglu 1993); however, some cultivars can be harvested at 12 inches in length. American slicer cucumbers were originally bred for open-field production, but some of the newly introduced parthenocarpic cultivars are recommended for hightunnel production (Bogash et al., 2014). Oriental cucumbers are further

\footnotetext{
Received for publication 2 Apr. 2019. Accepted for publication 15 July 2019.

Published online 27 August 2019.

${ }^{1}$ Department of Horticulture and Landscape Architecture, Purdue University, 625 Agriculture Mall Drive, West Lafayette, IN 47907

${ }^{2}$ University of Illinois Extension, Dixon Springs Agricultural Center, 354 State Highway 145 N, Simpson, IL 62985

${ }^{3}$ Department of Botany and Plant Pathology, Purdue University, 4369 North Purdue Road, Vincennes, IN 47591

${ }^{4}$ Department of Entomology, Purdue University, 901 W State Street, West Lafayette, IN 47907

This material is based upon work supported by the National Institute of Food and Agriculture, U.S. Department of Agriculture, under award number 2017-38640-26916 through the North Central Region SARE program under project number LNC17390 .

The USDA is an equal opportunity employer and service provider. Any opinions, findings, conclusions, or recommendations expressed in this publication are those of the author(s) and do not necessarily reflect the view of the USDA.

W.G. is the corresponding author. E-mail: guan40@ purdue.edu.

This is an open access article distributed under the CC BY-NC-ND license (https://creativecommons.org/ licenses/by-nc-nd/4.0/).

https://doi.org/10.21273/HORTTECH04370-19
}

divided into North Chinese, South Chinese, and Japanese types (Sakata et al., 2011). Japanese cultivars are hybrids of the South and North Chinese types. They are monoecious and produce fruit $\approx 8$ to 9 inches long; they have the greatest length:diameter ratio (Sakata and Sugiyama, 2002; Shetty and Wehner, 1998) and are cultivated in both open-field and protected cultural systems in Asia.

Multiple factors must be considered when evaluating parthenocarpic cucumber cultivars for high-tunnel production in the United States. Yield per plant is one of the most important factors determining the profitability of growing the crop in high tunnels. Plant vegetative growth is also of great interest to high-tunnel growers. Because cucumbers are normally grown with a single-leader trellising system, excessive side shoot growth requires increased labor for pruning and trellising.

Resistance to cucumber diseases and resistance to insect pests are other factors that are of great importance to high-tunnel growers. Chemical control of these issues may not be readily available for high-tunnel growers. Among various disease and insect pest challenges, powdery mildew and twospotted spider mites are the predominant pest problems encountered during cucumber production under protected cultural systems (Ingwell et al., 2018; Lamont et al., 2003; Morishita et al., 2003; Sabelis, 1984). High temperatures (77 to $86{ }^{\circ} \mathrm{F}$ ) and low relative humidity on the leaf surface create ideal conditions for powdery mildew development and two-spotted spider mite infestation (Shaw and Cantliffe, 2003). Many of the newly released greenhouse cucumber cultivars are marketed as having partial resistance to powdery mildew, but information regarding their comparative resistance to this disease is limited. Comparative resistance to two-spotted spider mites among cucumber cultivars has been previously reported (Maleknia et al., 2016), but little information regarding the selection of resistant cultivars for high-tunnel cucumber production is available. In the current study, we evaluated 16 cultivars from the four major types of parthenocarpic cucumbers at three locations with different management approaches.

\section{Materials and methods}

Parthenocarpic cucumber cultivar evaluation trials were conducted in protected structures at three locations: Southwest Purdue Agricultural Center (SWPAC), Vincennes, IN; Pinney Purdue Agricultural Center (PPAC), Wanatah, IN; and Dixon

Table 1. Cucumber type, cultivar, and seed source of each cucumber cultivar evaluated during the high-tunnel trials conducted in Spring 2018.

\begin{tabular}{clcl}
\hline Cucumber type & \multicolumn{1}{c}{ Cultivar } & $\begin{array}{c}\text { Harvest length } \\
\text { (inches) }^{\mathbf{z}}\end{array}$ & \multicolumn{1}{c}{ Seed source } \\
\hline $\begin{array}{c}\text { Dutch } \\
\text { greenhouse }\end{array}$ & Camaro & $13-15$ & Paramount Seeds, Stuart, FL \\
& Kalunga & $13-15$ & Paramount Seeds \\
& Tyria & $13-15$ & High Mowing Organic Seeds, \\
Beit alpha and & Katrina & $5-7$ & Polcott, VT \\
mini & Socrates & $5-7$ & High Mowing Organic Seeds \\
& Manny & $5-7$ & Harris Seeds, Rochester, NY \\
& Manar & $5-7$ & Paramount Seeds \\
& Jawell & $5-7$ & Paramount Seeds \\
Japanese & Picolino (mini) & $4-5$ & Harris Seeds \\
& Taurus & $8-10$ & Harris Seeds \\
& Tasty Jade & $10-12$ & Reimer Seeds, Mount Holly, \\
& & & NC \\
American slicer & Corinto & $10-12$ & Harris Seeds \\
& Lisboa & $7-9$ & Paramount Seeds \\
& Alcazar & $7-9$ & SeedWay, Hall, NY \\
& Sweet Success & $7-9$ & Siegers Seed Co., Holland, MI \\
\end{tabular}

${ }^{\mathrm{z}} 1$ inch $=2.54 \mathrm{~cm}$. 
Springs Agricultural Center (DSAC), Simpson, IL. The trials were conducted during Spring 2018. Cucumbers were grown in soils at SWPAC (Alvin sandy loam) and PPAC (Tracy sandy loam), and in a hydroponic system at the DSAC. Cucumber types, cultivars, and seed sources are listed in Table 1.

\section{Production practices, high-tunnel management, and experimental design}

Cucumber transplants were produced in greenhouses at each site. Seeds were sown in 50-cell trays using peat-based growing mixes at SWAPC (Sun Gro Horticulture; Agawam, MA), PPAC (ProMix Organic Vegetable and Herb; Premier Tech Horticulture, Quakertown, PA), and DSAC (ProMix BX with Biofungicide, Premier Tech Horticulture). Seedlings were transplanted in high tunnels when they developed three to four true leaves after growing in the greenhouses for $\approx 1$ month.

Southwest Purdue Agricultural Center. The experiment was conducted in a gothic-style high tunnel (Rimol Greenhouse Systems, Hooksett, NH) that was $30 \mathrm{ft}$ wide and $96 \mathrm{ft}$ long, with 6 - $\mathrm{ft}$ side walls and $15-\mathrm{ft}$ centers. The high tunnel was equipped with a ridge vent, which opened when temperatures inside the high tunnel reached 75 ${ }^{\circ} \mathrm{F}$ and closed when temperatures dropped below $60^{\circ} \mathrm{F}$. The side walls were opened when temperatures inside high tunnel were more than $80^{\circ} \mathrm{F}$. Cucumber plants were transplanted in the high tunnel on 12 Apr. into raised beds with 4 -ft center-tocenter bed spacing. Beds were covered with black plastic mulch with one drip tape with 8-inch emitter spacing in the middle of each bed. The in-row plant spacing was $1 \mathrm{ft}$ apart. Plants were fertigated three times per day beginning 2 weeks after transplanting with potassium nitrate (13.7N-0P-38.5K) (Krista K; Yara International, Oslo, Norway) and urea ammonium nitrate solution (28N-0P-0K) (CF Industries Holdings, Deerfield, IL) at a rate of $1 \mathrm{lb} /$ acre nitrogen $(\mathrm{N})$ per day in May, and $1.5 \mathrm{lb} /$ acre $\mathrm{N}$ per day in June and July. A total of $128 \mathrm{lb} /$ acre $\mathrm{N}$ was applied during the season. Water application rate ranged from 60 to $270 \mathrm{gal} / \mathrm{d}$ per high tunnel. Irrigation started at $20 \mathrm{gal}$ of water for each irrigation event for the entire high tunnel in May; then, it was gradually increased to $90 \mathrm{gal}$ of water for each irrigation event in July. Irrigation was paused on rainy days. Throughout the season, soil moisture was maintained around field capacity. A soil moisture sensor (5TE; Meter Group, Pullman, WA) was used to guide irrigation management. The average volumetric water content was $\approx 0.2 \mathrm{~m}^{3} \cdot \mathrm{m}^{-3}$ at a soil depth of 10 inches.

Potassium salts of fatty acids (MPede; Dow AgroSciences, Indianapolis, IN) at a rate of $0.076 \mathrm{lb} / \mathrm{gal}$ a.i. were sprayed on 8,16 , and 24 May, and on 20 June for aphids (Aphididae) and two-spotted spider mite control. Bifenazate (Acramite 50WS; Chemtura Corp., Middlebury, CT) at a rate of $0.37 \mathrm{lb} /$ acre a.i. was sprayed on 20 June for two-spotted spider mite control.

The cucumber plants were trellised to a single leader system. Side shoots were pruned weekly. Old foliage at the base of the plant was pruned biweekly, leaving $\approx 15$ fully expanded newer leaves on each plant. The same pruning method was used at the three sites. Vines were then lowered to the ground. A randomized complete block design with four replications and four plants per cultivar per replication was used in the experiment.

Pinney Purdue Agricultural Center. The experiment was conducted in a gothic-style high tunnel (Rimol Greenhouse Systems) that was $30 \mathrm{ft}$ wide and $48 \mathrm{ft}$ long, with 4 - $\mathrm{ft}$ side walls and 14 - $\mathrm{ft}$ centers. Side walls were thermostatically controlled and set to open when temperatures inside the high tunnel were above 80 ${ }^{\circ} \mathrm{F}$ and close to below $60^{\circ} \mathrm{F}$. End walls were left open after 6 June. Cucumber plants were transplanted in the high tunnel on 23 May into raised beds with 4 -ft center-to-center bed spacing. The beds were covered with black plastic mulch with two lines of drip tape with 12 -inch emitter spacing along each side of the plant row. Plants were $\mathrm{l} f \mathrm{ft}$ apart in the plot. Fertilizer was incorporated when beds were formed at a rate of 100 $\mathrm{lb} /$ acre $\mathrm{N}$ from $46 \mathrm{~N}-0 \mathrm{P}-0 \mathrm{~K}$ (Shaw's Turf Food; Knox Fertilizer Co., Knox, IN) and $100 \mathrm{lb} /$ acre $\mathrm{K}$ from 0N-0P-50K (Kova, Greensburg,
IN). Plants were irrigated manually after transplanting. After establishment, plants were irrigated every day or every few days based on observations of soil moisture and weather conditions, with 50 to $150 \mathrm{gal} / \mathrm{tun}$ nel supplied per day. To assist with monitoring soil moisture, dielectric soil moisture sensors (10HS Soil Moisture Smart Sensor; Onset Computer Corp., Bourne MA) were installed at depths of 6 and 12 inches. Sensor readings logged every $10 \mathrm{~min}$ utes recorded an average daily minimum volumetric water content of 0.282 at the 6-inch depth and 0.305 at the 12-inch depth for the period from 16 June to 8 Aug.

Permethrin (Arctic 3.2EC; Winfield Solutions, St. Paul, MN) at a rate of $0.2 \mathrm{lb} /$ acre a.i. and acequinocyl (Kanemite; Arysta LifeScience North America, Cary, NC) at a rate of 0.3 lb/acre a.i. were applied on 13 July for striped cucumber beetles (Acalymma vittatum) and squash bugs (Anasa tristis) control. A randomized complete block design was used during the experiment, with six replications and two plants per cultivar per replication.

Dixon Springs Agricultural Center. Cucumber plants were grown in a $35-\times 96-\mathrm{ft}$ gothic-style tunnel (Zimmerman's High Tunnels and Greenhouses, Versailles, MO) with fixed sidewall curtains and end walls. Air temperature in this tunnel was regulated by a thermostat set at $80{ }^{\circ} \mathrm{F}$, and shutters and exhaust fans were opened and closed accordingly. Two horizontal airflow fans continually circulated air to help reduce humidity. A $30 \%$ shadecloth was installed on the tunnel on 1 June. The floor of this tunnel was limestone gravel.

Cucumber plants were transplanted into hydroponic greenhouse pots (Bato-bucket; Bato Plastics, Zevenbergen, the Netherlands) filled with perlite (Aero-Soil horticultural Perlite; Chem-Rock Co., Jacksonville, FL) on 23 Apr. Two plants were placed in one pot. The pots were placed 18 inches apart in rows that were 5 -ft center-to-center. The fertigation schedule was based on plant water needs. One week after transplanting, each plant received 1 gal of water per day with $0.01 \mathrm{lb}$ complete fertilizer $(3 \mathrm{~N}-6.5 \mathrm{P}-23.2 \mathrm{~K})$ (Ultrasol; SQM North America Corp., 
Atlanta, GA) and $0.005 \mathrm{lb}$ calcium nitrate $(15.5 \mathrm{~N}-0 \mathrm{P}-0 \mathrm{~K})$ (YaraLiva Calcinit; Yara United States, Tampa, FL). The fertigation solution was maintained at $1.8 \mathrm{mS} \cdot \mathrm{cm}^{-1} \mathrm{EC}$ and $6.5 \mathrm{pH}$. Plants were spaced at $3.75 \mathrm{ft}^{2}$ per plant. A total of $0.097 \mathrm{lb} \mathrm{N}$ per plant was delivered during the course of the trial.

Flonicamid (Beleaf 50SG; FMC Corp., Philadelphia, PA) was sprayed at a rate of $0.062 \mathrm{lb} /$ acre a.i. on 1 June for aphid control; Bacillus thuringiensis (DiPel DF; Valent U.S.A. Corp., Walnut Creek, CA) was sprayed at a rate of $0.54 \mathrm{lb} /$ acre a.i. on 8,15 , and 29 June, and on 13 and 20 July for caterpillar (Lepidoptera) control. Permethrin (Perm-Up 3.2 EC; United Phosphorus, King of Prussia, PA) was sprayed at a rate of $0.2 \mathrm{lb} /$ acre a.i. on $18 \mathrm{May}, 29$ June, and 13 July for striped cucumber beetle control. A randomized complete block design with four replications and four plants per cultivar per replication was used during the experiment.

\section{Data collection}

At all locations, cucumbers were harvested three times per week. Harvest size was determined according to seed suppliers and are listed in Table 1.

Cucumbers were separated into marketable fruit and culls according to the United States Department of Agriculture (USDA) standards for greenhouse cucumbers (U.S. Department of Agriculture, 1985). Unmarketable fruit were further separated into scarred fruit (scarring was mainly caused by insect feeding damage or mechanical injury) and misshaped fruit (tapering at the blossom end or curved fruit). Plant sexual type, node of the first female flower, and the number of female flowers at each node were observed and recorded at SWPAC and confirmed at other locations.

The lengths of the plant stems were measured every other week. The fresh weight of pruned side shoots from each experimental plot was determined weekly at SWPAC. Plant resistance to powdery mildew was rated weekly using the Horsfall-Barratt rating scale (Horsfall and Barratt, 1945) between 19 June and 24 July at SWPAC. The area under the disease progress curve (AUDPC) was calculated by trapezoidal integration (Shaner and Finney, 1977). Plant susceptibility to two-spotted spider mites was also evaluated using the Horsfall-Barratt scale to rate leaf symptoms. The evaluation was conducted on 24 July at SWPAC during peak mite infestation.

\section{Statistical analyses}

Data from the three experimental sites were analyzed separately. An analysis of variance was performed using the Proc Glimmix program of SAS statistical software package (version 9.4 for Windows; SAS Institute, Cary, NC). Fisher's least significant difference test ( $\alpha=0.05)$ was conducted for multiple comparisons of different measurements among treatments.

\section{Results and discussion}

Cucumber YIELD. Harvests lasted from 7 May to 30 July, 14 May to 30 July, and 13 June to 8 Aug. at SWPAC, DSAC, and PPAC, respectively. Harvest of Beit alpha and mini cucumbers started less than 30 $\mathrm{d}$ after transplanting. The American slicer cultivars were harvested 3 to 4 d later than Beit alpha and mini cucumbers. The harvest of Dutch greenhouse and Japanese cultivars started 1 to 2 weeks later than that of any of the other cultivars.

The total yields of cucumbers ranged from 14.0 to $23.3 \mathrm{lb} /$ plant at SWPAC, 13.5 to $19.8 \mathrm{lb} /$ plant at DSAC, and 7.4 to $16.3 \mathrm{lb} /$ plant at PPAC (Table 2). Overall yields at PPAC were lower than those at SWPAC and DSAC. A shorter harvest period and the different fertility management may have contributed to the yield difference. At PPAC, fertilizers were applied preplant following the recommendations of field-grown cucumbers (Egel et al., 2018). Because of the extended harvest in high tunnels compared with field production, fruit abortion and yellowing of old leaves were observed on these cucumber plants, especially toward the end of the production season. Plant tissue analyses confirmed low nitrogen and deficient potassium levels in these plants (data not shown). At SWPAC and DSAC, plants were fertigated daily following the recommendations for greenhouse cucumber production (Papadopoulos, 1994). Nutrient deficiency symptoms were not detected at these locations.

At each location, the cultivar that produced the highest total yield was a Beit alpha or mini type; these were Picolino, Jawell, and Manny at SWPAC, DSAC, and PPAC, respectively (Table 2 ). Beit alpha cucumbers are known for high productivity (Cantliffe et al., 2004). Under optimal growing conditions, three to five fruit may be harvested at each node (Shaw et al., 2000).

At SWPAC, Beit alpha cucumbers, except for 'Jawell', had total yield similar to the highest-yielding cultivar Picolino. The total yields of Japanese cultivars Tasty Jade and Taurus and American slicer cultivars Sweet Success and Corinto were also similar to that of Picolino. At PPAC, Beit alpha cultivars Manny, Katrina, and Socrates had the highest total yields, and they were not significantly different from the 'Corinto' American slicer cucumber. At DSAC, total yields were not significantly different among all the Beit alpha and mini, Dutch greenhouse, and Japanese cultivars Tasty Jade and Taurus, but the yields of American slicer cucumbers, except Sweet Success, were lower. Consistently among the three sites, 'Tasty Green' Japanese cucumber had the lowest total yield among the evaluated cultivars.

Averaged among cultivars, unmarketable fruit accounted for $\approx 30 \%$ of the total yield at SWPAC and PPAC (Table 3). Unmarketable fruit could be further divided as misshaped and scarred fruit. Fruit that were categorized as misshaped were either severely curved or tapered (U.S. Department of Agriculture, 1985). 'Sweet Success' had a high percentage of misshaped fruit, especially at SWPAC, which accounted for $36.9 \%$ of the total yield. The majority of the misshaped fruit had tapering at the blossom end. The three Dutch greenhouse cultivars had an average of $25.7 \%$ and $15.8 \%$ misshaped fruit at SWPAC and PPAC, respectively. Japanese cultivars Tasty Jade and Tasty Green also had higher percentages of misshaped fruit that accounted for $16.2 \%$ and $14.3 \%$ of the total yields at SWPAC and PPAC, respectively. Those misshaped fruit mainly had curving.

American slicers 'Corinto', 'Lisboa', and 'Alcazar' and the Beit alpha cultivars had lower percentages of 


\section{Preliminary and Regional Reports}

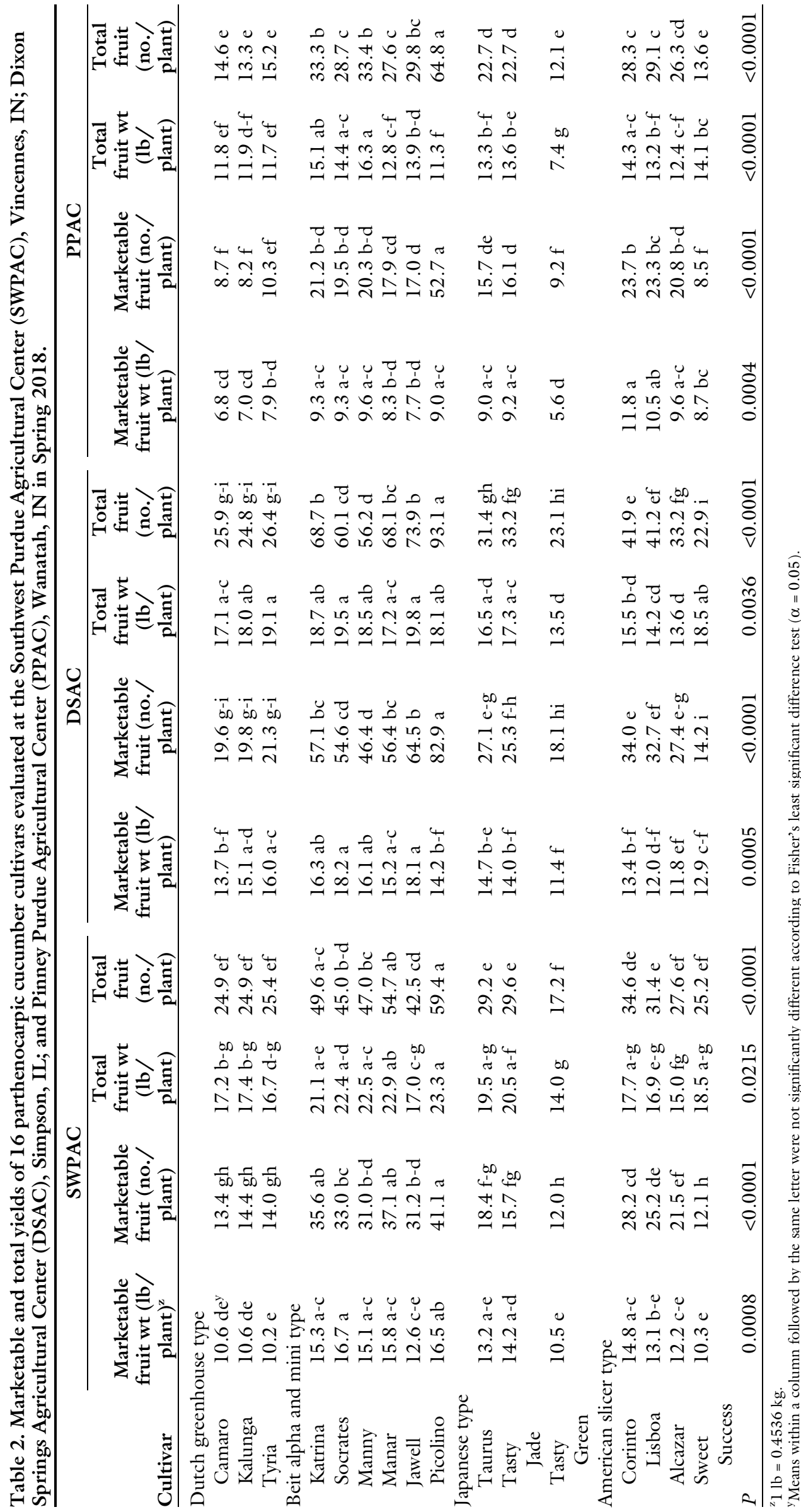


Table 3. Percentages of marketable fruit, misshaped fruit, and scarred fruit during the cucumber cultivar evaluation trials conducted at the Southwest Purdue Agricultural Center (SWPAC), Vincennes, IN and Pinney Purdue Agricultural Center (PPAC), Wanatah, IN in Spring 2018.

\begin{tabular}{|c|c|c|c|c|c|c|}
\hline \multirow{2}{*}{ Cultivar } & \multicolumn{2}{|c|}{ Marketable fruit (\%) } & \multicolumn{2}{|c|}{ Misshaped fruit $(\%)^{\mathrm{z}}$} & \multicolumn{2}{|c|}{ Scarred fruit $(\%)^{\mathrm{y}}$} \\
\hline & SWPAC & PPAC & SWPAC & PPAC & SWPAC & PPAC \\
\hline \multicolumn{7}{|c|}{ Dutch greenhouse type } \\
\hline Camaro & $62.7 \mathrm{e}-\mathrm{g}^{\mathrm{x}}$ & $58.1 \mathrm{~d}$ & $25.0 \mathrm{bc}$ & $21.5 \mathrm{a}$ & $12.1 \mathrm{~cd}$ & $20.3 \mathrm{e}-\mathrm{g}$ \\
\hline Kalunga & $61.5 \mathrm{fg}$ & $5 \mathrm{~d}$ & $23.1 \mathrm{c}$ & $11.4 \mathrm{bc}$ & $15.4 \mathrm{bc}$ & $31.1 \mathrm{~b}-\mathrm{d}$ \\
\hline Tyria & $61.0 \mathrm{fg}$ & $65.9 \mathrm{a}-\mathrm{d}$ & $29.0 \mathrm{~b}$ & $14.5 \mathrm{~b}$ & $9.8 \mathrm{~cd}$ & $19.6 \mathrm{e}-\mathrm{g}$ \\
\hline \multicolumn{7}{|c|}{ Beit alpha and mini type } \\
\hline Katrina & $72.6 \mathrm{~d}$ & $61.0 \mathrm{~cd}$ & $4.5 \mathrm{e}$ & $1.5 \mathrm{e}$ & $22.6 \mathrm{a}$ & $37.5 \mathrm{ab}$ \\
\hline Socr & $74.6 \mathrm{~b}-\mathrm{d}$ & $64.1 \mathrm{~b}-\mathrm{d}$ & $4.6 \mathrm{e}$ & $1.8 \mathrm{de}$ & $20.7 \mathrm{ab}$ & $34.1 \mathrm{a}-\mathrm{d}$ \\
\hline Manny & $68.3 \mathrm{~d}-\mathrm{f}$ & $57.8 \mathrm{~d}$ & $7.0 \mathrm{e}$ & $2.3 \mathrm{de}$ & $24.6 \mathrm{a}$ & $39.8 \mathrm{ab}$ \\
\hline Manar & $69.8 \mathrm{~d}-\mathrm{f}$ & $63.5 \mathrm{~b}-\mathrm{d}$ & $6.5 \mathrm{e}$ & $1.2 \mathrm{e}$ & $23.4 \mathrm{a}$ & $35.2 \mathrm{a}-\mathrm{c}$ \\
\hline Jas & $74.9 \mathrm{a}-\mathrm{d}$ & $55.6 \mathrm{~d}$ & $3.3 \mathrm{e}$ & $1.0 \mathrm{e}$ & $21.5 \mathrm{ab}$ & $43.4 \mathrm{a}$ \\
\hline Picolino & $71.5 \mathrm{de}$ & $80.0 \mathrm{ab}$ & $3.5 \mathrm{e}$ & $2.6 \mathrm{de}$ & $24.9 \mathrm{a}$ & $17.3 \mathrm{e}-\mathrm{g}$ \\
\hline \multicolumn{7}{|l|}{ Japanese type } \\
\hline Taurus & $68.4 \mathrm{~d}-\mathrm{f}$ & $a-d$ & $5.1 \mathrm{e}$ & $7.8 \mathrm{~cd}$ & 26. & $25.8 \mathrm{c}-\mathrm{e}$ \\
\hline Tasty Jade & $69.3 \mathrm{~d}-\mathrm{f}$ & $66.4 \mathrm{a}-\mathrm{d}$ & $15.2 \mathrm{~d}$ & $16.5 \mathrm{ab}$ & $15.3 \mathrm{bc}$ & $17.1 \mathrm{e}-\mathrm{g}$ \\
\hline Tasty Green & $74.2 \mathrm{~cd}$ & $75.1 \mathrm{a}-\mathrm{c}$ & $17.3 \mathrm{~d}$ & $12.2 \mathrm{bc}$ & $8.4 \mathrm{~d}$ & $12.6 \mathrm{~g}$ \\
\hline \multicolumn{7}{|c|}{ American slicer type } \\
\hline Corinto & $83.6 \mathrm{a}$ & $82.3 \mathrm{a}$ & $7.5 \mathrm{e}$ & $3.1 \mathrm{de}$ & $8.9 \mathrm{~cd}$ & $14.5 \mathrm{fg}$ \\
\hline Lisboa & $83.3 \mathrm{ab}$ & $79.4 \mathrm{ab}$ & $7.8 \mathrm{e}$ & $1.8 \mathrm{de}$ & $8.9 \mathrm{~cd}$ & $18.8 \mathrm{e}-\mathrm{g}$ \\
\hline Alcazar & $81.8 \mathrm{a}-\mathrm{c}$ & $77.1 \mathrm{a}-\mathrm{c}$ & $8.7 \mathrm{e}$ & $3.3 \mathrm{de}$ & $9.5 \mathrm{~cd}$ & $19.6 \mathrm{e}-\mathrm{g}$ \\
\hline Sweet Success & $55.4 \mathrm{~g}$ & $61.9 \mathrm{~cd}$ & $36.9 \mathrm{a}$ & $14.2 \mathrm{~b}$ & $7.6 \mathrm{~d}$ & $23.8 \mathrm{~d}-\mathrm{f}$ \\
\hline$P$ & $<0.0001$ & $<0.0001$ & $<0.0001$ & $<0.0001$ & $<0.0001$ & $<0.0001$ \\
\hline
\end{tabular}

${ }^{\mathrm{z}}$ Misshaped fruit include curved or tapering fruit.

yscarred fruit include fruit with skin damage caused by cucumber beetles, squash bugs, caterpillars, or mechanical injury such as scratching from trellising strings or trellis clips.

${ }^{x}$ Means within a column followed by the same letter were not significantly different by Fisher's least significant difference test $(\alpha=0.05)$.

misshaped fruit. However, a large percentage of Beit alpha cucumbers had scarred fruit because of either insect feeding damage or mechanical injury. Among the evaluated cultivars, Corinto had the highest fruit marketability; Lisboa and Alcazar also had high fruit marketability at both SWPAC and PPAC.

Unmarketable fruit comprised less than $15 \%$ at DSAC (data not shown), where cucumbers were grown in a structure that was equipped with fixed sidewall curtains and end walls, and temperatures were controlled through opening and closing shutters and exhaust fans. In contrast, at PPAC and SWPAC, side and end walls of the high tunnels remained open most of the time when temperatures were above $80^{\circ} \mathrm{F}$, and plants were exposed to wind. Fruit became scarred by rubbing on plant parts, strings, or clips. The open environment also allowed the entry of insect pests such as cucumber beetles (A. vittatum and Diabrotica undecimpunctata), squash bugs, and yellow striped armyworms (Spodoptera ornithogalli), which caused aesthetic damage to fruit skins. The open environment also facilitated pollination. It is known that parthenocarpic cucumbers may develop misshaped fruit when female flowers are pollinated (Papadopoulos, 1994). However, these undesirable effects due to the open high-tunnel environment were seldom observed on American slicer cultivars. This was particularly noticed for 'Corinto', which had the highest marketable yield at PPAC and one of the highest marketable yields at SWPAC.

Interestingly, the average total yield of Beit alpha and mini cucumbers was $7.6 \mathrm{lb} /$ plant lower at PPAC than at SWPAC, whereas the yield difference between the two sites was 3 lb/plant for American slicer cucumbers (cultivars Corinto, Lisboa, and Alcazar). A similar trend was also observed when comparing the yields of Beit alpha cucumbers and American slicer cucumbers at DSAC and PPAC (Table 2). The relatively better performance of 'Corinto', 'Lisboa', and 'Alcazar' compared with Beit alpha and mini cucumbers at PPAC may suggest that American slicer cucumbers are better adapted to production systems that do not rely on intensive fertigation compared with Beit alpha and mini cucumbers.

The marketable fruit number varied greatly among cultivars and cucumber types (Table 2). Generally, cultivars with smaller cucumbers produced greater numbers, and cultivars with larger cucumbers produced fewer. For example, cultivar Picolino, harvested at the shortest length, consistently produced the most fruit per plant. In contrast, Dutch greenhouse-type cucumbers, Japanese cucumbers, and 'Sweet Success', all harvested at longer lengths, produced the least number of fruit.

Plant vegetative growth. The growth rate of cucumber main stems and the growth of side shoots are of great importance to growers because they influence the amount of labor needed for trellising and pruning the cucumber plants in a singlestem vertical growing system. Among the evaluated cultivars, Tasty Green produced the most side shoot growth. Fresh weight of these shoots was significantly greater than that of other cultivars, except Taurus (Table 4). 'Lisboa' developed the least side shoot growth and was not significantly different from 'Jawell', 'Corinto', 'Katrina', 'Sweet Success', 'Tyria', and 'Manny'. Consistent among the three locations, 'Corinto' was one of the cultivars that had the greatest length of main stems 1 month after transplanting. The main stems of 'Tasty Green' and 'Alcazar' also grew faster than those of the majority of the other cultivars.

Plant SEXUAL TYPe. Location of the first female flower is important because it influences early yield. For long cucumbers, it also provides an indication of whether the first flower should be allowed to produce fruit; if the node is too close to the ground, then the cucumber may touch the ground, curve, and become unmarketable. Dutch greenhouse, Beit alpha and mini, and the American slicer cultivars that were selected for the evaluation are gynoecious plants that produce only female flowers. The first female flower developed on the second or third node of American slicer 
Table 4. Fresh weight of side shoots and the length of main stems during the cucumber cultivar evaluations conducted the Southwest Purdue Agricultural Center (SWPAC), Vincennes, IN; Dixon Springs Agricultural Center (DSAC), Simpson, IL; and Pinney Purdue Agricultural Center (PPAC), Wanatah, IN in Spring 2018.

\begin{tabular}{|c|c|c|c|c|}
\hline \multirow[b]{2}{*}{ Cultivar } & \multirow[b]{2}{*}{ Side shoot fresh wt $(\mathrm{g})^{\mathrm{z}}$} & \multicolumn{3}{|c|}{ Length of main stem $(\mathrm{cm})^{\mathrm{y}}$} \\
\hline & & SWPAC & DSAC & PPAC \\
\hline \multicolumn{5}{|c|}{ Dutch greenhouse type } \\
\hline Camaro & $78.5 \mathrm{~d}-\mathrm{f}^{\mathrm{x}}$ & $99.1 \mathrm{e}-\mathrm{g}$ & $97.8 \mathrm{~g}-\mathrm{f}$ & $120.7 \mathrm{gh}$ \\
\hline Kalunga & $74.4 \mathrm{~d}-\mathrm{f}$ & $76.0 \mathrm{~h}$ & $87.9 \mathrm{~g}-\mathrm{i}$ & $122.5 \mathrm{f}-\mathrm{h}$ \\
\hline Tyria & $52.1 \mathrm{f}-\mathrm{i}$ & $86.6 \mathrm{gh}$ & $112.1 \mathrm{de}$ & $120.1 \mathrm{gh}$ \\
\hline \multicolumn{5}{|c|}{ Beit alpha and mini type } \\
\hline Katrina & $37.9 \mathrm{~g}-\mathrm{i}$ & $86.7 \mathrm{gh}$ & $82.5 \mathrm{hi}$ & $115.0 \mathrm{~h}$ \\
\hline Socrates & $86.4 \mathrm{c}-\mathrm{e}$ & $121.9 \mathrm{bc}$ & $108.9 \mathrm{~d}-\mathrm{f}$ & $141.6 \mathrm{~b}-\mathrm{e}$ \\
\hline Manny & $52.2 \mathrm{f}-\mathrm{i}$ & $107.4 \mathrm{de}$ & $118.7 \mathrm{~d}$ & $144.8 \mathrm{~b}-\mathrm{d}$ \\
\hline Manar & $102.2 \mathrm{~b}-\mathrm{d}$ & $98.1 \mathrm{e}-\mathrm{g}$ & $94.9 \mathrm{f}-\mathrm{h}$ & $123.4 \mathrm{f}-\mathrm{h}$ \\
\hline Jawell & 30.1 hi & $96.8 \mathrm{e}-\mathrm{g}$ & $85.7 \mathrm{~g}-\mathrm{i}$ & $132.8 \mathrm{~d}-\mathrm{g}$ \\
\hline Picolino & $61.2 \mathrm{e}-\mathrm{h}$ & $91.1 \mathrm{fg}$ & $78.4 \mathrm{i}$ & $128.6 \mathrm{e}-\mathrm{g}$ \\
\hline \multicolumn{5}{|l|}{ Japanese type } \\
\hline Taurus & $128.4 \mathrm{ab}$ & $102.1 \mathrm{ef}$ & $106.7 \mathrm{~d}-\mathrm{f}$ & $135.4 \mathrm{c}-\mathrm{f}$ \\
\hline Tasty Jade & $65.7 \mathrm{e}-\mathrm{g}$ & $104.9 \mathrm{ef}$ & $99.7 \mathrm{e}-\mathrm{g}$ & $141.1 \mathrm{~b}-\mathrm{e}$ \\
\hline Tasty Green & $153.2 \mathrm{a}$ & $137.6 \mathrm{a}$ & $135.6 \mathrm{bc}$ & $153.5 \mathrm{~b}$ \\
\hline \multicolumn{5}{|c|}{ American slicer type } \\
\hline Corinto & 30.9 hi & $137.9 \mathrm{a}$ & $147.0 \mathrm{ab}$ & $174.1 \mathrm{a}$ \\
\hline Lisboa & $28.7 \mathrm{i}$ & $121.2 \mathrm{~cd}$ & $146.0 \mathrm{ab}$ & $151.9 \mathrm{~b}$ \\
\hline Alcazar & $110.5 \mathrm{bc}$ & $135.4 \mathrm{ab}$ & $154.9 \mathrm{a}$ & $147.5 \mathrm{bc}$ \\
\hline Sweet Success & $40.1 \mathrm{~g}-\mathrm{i}$ & $119.8 \mathrm{~cd}$ & $120.6 \mathrm{~cd}$ & $151.9 \mathrm{~b}$ \\
\hline$P$ & $<0.0001$ & $<0.0001$ & $<0.0001$ & $<0.0001$ \\
\hline
\end{tabular}

${ }^{\mathrm{z}}$ Side shoot fresh weight was the total fresh weight of suckers pruned on $1,8,15,21$, and 30 May 2018 during the trial conducted at the SWPAC; $1 \mathrm{~g}=0.0353 \mathrm{oz}$.

yPlant heights were measured 33,32 , and $30 \mathrm{~d}$ after transplanting at SWPAC, DSAC, and PPAC, respectively. The data were collected from two plants in each experimental plot. The average of the two measurements was used for statistical analyses; $1 \mathrm{~cm}=0.3937$ inch

${ }^{x}$ Means within a column followed by the same letter were not significantly different according to Fisher's least significant difference test $(\alpha=0.05)$.

Table 5. Plant sexual type, node of the first female flower, and the number of female flowers at each node of parthenocarpic cucumber cultivars evaluated during the cultivar evaluation trials conducted at the Southwest Purdue Agricultural Center (SWPAC), Vincennes, IN; Dixon Springs Agricultural Center (DSAC), Simpson, IL; and Pinney Purdue Agricultural Center (PPAC), Wanatah, IN in Spring 2018. ${ }^{\mathrm{z}}$

\begin{tabular}{|c|c|c|c|}
\hline $\begin{array}{l}\text { Cucumber } \\
\text { type }^{y}\end{array}$ & $\begin{array}{c}\text { Plant sex } \\
\text { type }\end{array}$ & $\begin{array}{l}\text { Node no. of the first } \\
\text { female flower }\end{array}$ & $\begin{array}{c}\text { Female flowers at each } \\
\text { node (no.) }\end{array}$ \\
\hline $\begin{array}{l}\text { Dutch } \\
\quad \text { greenhouse }\end{array}$ & Gynoecious & $3-5$ & 1 \\
\hline $\begin{array}{l}\text { Beit alpha or } \\
\text { mini }\end{array}$ & Gynoecious & $2-3$ & $1-5$ \\
\hline Japanese & Monoecious & $4-6$ & 1 \\
\hline American slicer & Gynoecious & $2-3$ & 1 \\
\hline
\end{tabular}

${ }^{\mathrm{z}}$ Similar observations were made at the three locations.

${ }^{y}$ Different cucumber cultivars within each of the cucumber types performed similarly; therefore, the information is presented based on cucumber types.

and Beit alpha and mini types, and on the third to fifth node of Dutch greenhouse types (Table 5). Female flowers then produced on each subsequent node on the main stem of the plant. Japanese cultivars are monoecious plants that bear both male and female flowers. The plants produce male flowers initially. The first female flowers were initiated on the fourth to sixth node on the main stem.

Monoecious cultivars have not been recommended for greenhouse cucumber production because they require more pruning, take longer to produce fruit, and have lower yields (Papadopoulos, 1994). Furthermore, the monoecious cultivar
Tasty Green had a lower yield and greater vegetative growth. However monoecious cultivars Tasty Jade and Taurus showed promising yield potential. The development of side shoots by 'Tasty Jade' was comparable to that of most gynoecioustype cultivars.

Comparative resistance to POWDERY MILDEW AND TWO-SPOTTED SPIDER MITES. Plant resistance to powdery mildew varied greatly among cultivars at SWPAC. The Japanese cultivar Tasty Jade had significantly more powdery mildew than all other cultivars (Table 6). 'Taurus' was also moderately susceptible to powdery mildew. Among the Dutch greenhouse cultivars, 'Kalunga' was significantly more susceptible to the disease, whereas 'Tyria' was the least susceptible cultivar. In the group of Beit alpha and mini cucumbers, 'Jawell' had significantly more disease than the other cultivars, although the disease severity was significantly lower than that of 'Tasty Jade', 'Taurus', 'Kalunga', and 'Camaro'. All the American slicer cultivars evaluated during this trial were fairly resistant to this disease. A similar trend was observed at DSAC (data not shown).

Cucumber resistance to powdery mildew is controlled by multiple genes, and this resistance is known to be temperature-dependent (Pierce and Wehner, 1990). Sakata et al. (2006) argued that although several commercial cultivars show resistance to powdery mildew under high-temperature conditions, there was no resistant cultivar for greenhouse production from winter to spring. Considering the quantitative disease resistance characteristic, in-depth pathogenic studies are warranted to further quantify the disease resistance to powdery mildew among the different types of cucumber cultivars under diverse environmental conditions.

Comparative resistance to twospotted spider mites among cucumber cultivars has been previously reported (Maleknia et al., 2016). In the current study, we noticed Japanese cucumber cultivars had less leaf damage caused by two-spotted spider mites compared with the other cucumber types (Table 7). However, there was no significant difference in leaf damage caused by two-spotted spider mites among the other types of cucumbers. Plant resistance toward 
Table 6. Resistance of cucumber cultivars to powdery mildew as measured by the area under the disease progress curve (AUDPC) during the cucumber cultivar evaluation trial conducted at the Southwest Purdue Agricultural Center, Vincennes, IN in Spring 2018.

\begin{tabular}{lr}
\hline Cultivar & AUDPC $^{\mathbf{z}}$ \\
\hline Dutch greenhouse type & \\
Camaro & $1104.4 \mathrm{c}^{\mathrm{y}}$ \\
Kalunga & $2308.1 \mathrm{~b}$ \\
Tyria & $670.7 \mathrm{~d}$ \\
Beit alpha and mini type & \\
Katrina & $74.7 \mathrm{e}$ \\
Socrates & $48.3 \mathrm{e}$ \\
Manny & $68.8 \mathrm{e}$ \\
Manar & $66.3 \mathrm{e}$ \\
Jawell & $574.2 \mathrm{~d}$ \\
Picolino & $63.1 \mathrm{e}$ \\
Japanese type & \\
Taurus & $1462.9 \mathrm{c}$ \\
Tasty Jade & $4058.3 \mathrm{a}$ \\
Tasty Green & $403.9 \mathrm{de}$ \\
American slicer type & \\
Corinto & $121.1 \mathrm{e}$ \\
Lisboa & $73.1 \mathrm{e}$ \\
Alcazar & $99.5 \mathrm{e}$ \\
Sweet Success & $84.2 \mathrm{e}$ \\
$P$ & $<0.0001$ \\
\hline
\end{tabular}

${ }^{\mathrm{z}}$ Disease severity was evaluated using the HorsfallBarratt rating scale on 19 and 25 June and $1,8,18$ and 24 July. Horsfall-Barratt rating scale: $1=0 \%$ disease severity; $2=0 \%$ to $3 \%$ disease severity; $3=3 \%$ to $6 \%$ disease severity; $4=6 \%$ tol $2 \%$ disease severity; $5=$ $12 \%$ to $25 \%$ disease severity; $6=25 \%$ to $50 \%$ disease severity; $7=50 \%$ to $75 \%$ disease severity; $8=75 \%$ to $88 \%$ disease severity; $9=88 \%$ to $94 \%$ disease severity; $10=94 \%$ to $97 \%$ disease severity; $11=97 \%$ to $100 \%$ disease severity; $12=100 \%$ disease severity (Horsfal and Barratt, 1945). AUDPC was calculated by trapezoidal integration (Shaner and Finney, 1977).

${ }^{\mathrm{y}}$ Means within a column followed by the same letter were not significantly different according to Fisher's least significant difference test $(\alpha=0.05)$.

insect pests could be governed by plants forming characteristics that adversely affect insect biology, repel insects from the host, or tolerate insect attacks (War et al., 2012). It will be interesting to further investigate potential plant defense mechanisms of the less damaged cultivars against two-spotted spider mite attacks.

\section{Conclusions}

Selecting cultivars to grow in high-tunnel environments is a complex process. Selection criteria include overall productivity, plant growth habit, disease resistance, and consumer preference. In the United States, consumers are familiar with traditional slicer cucumbers that are
Table 7 . Susceptibility of cucumber cultivars to two-spotted spider mites during the cucumber cultivar evaluation trial conducted at the Southwest Purdue Agricultural Center, Vincennes, IN in Spring 2018.

\begin{tabular}{|c|c|}
\hline Cultivar & Rating $^{\mathbf{z}}$ \\
\hline \multicolumn{2}{|c|}{ Dutch greenhouse type } \\
\hline Camaro & $5.5 \mathrm{a}^{\mathrm{y}}$ \\
\hline Kalunga & $6.0 \mathrm{a}$ \\
\hline Tyria & $6.0 \mathrm{a}$ \\
\hline \multicolumn{2}{|c|}{ Beit alpha and mini type } \\
\hline Katrina & $7.0 \mathrm{a}$ \\
\hline Socrates & $4.7 \mathrm{ab}$ \\
\hline Manny & $6.2 \mathrm{a}$ \\
\hline Manar & $4.7 \mathrm{ab}$ \\
\hline Jawell & $7.0 \mathrm{a}$ \\
\hline Picolino & $5.7 \mathrm{a}$ \\
\hline \multicolumn{2}{|l|}{ Japanese type } \\
\hline Taurus & $2.2 \mathrm{bc}$ \\
\hline Tasty Jade & $1 \mathrm{c}$ \\
\hline Tasty Green & $2.2 \mathrm{bc}$ \\
\hline \multicolumn{2}{|c|}{ American slicer type } \\
\hline Corinto & $4.2 \mathrm{ab}$ \\
\hline Lisboa & $4.2 \mathrm{ab}$ \\
\hline Alcazar & $5.7 \mathrm{a}$ \\
\hline Sweet Success & $5.2 \mathrm{a}$ \\
\hline$P$ & $<0.0001$ \\
\hline \multicolumn{2}{|c|}{$\begin{array}{l}{ }^{z} \text { The severity of plant leaf damage caused by two- } \\
\text { spotted spider mites was evaluated using the Horsfall- } \\
\text { Barratt rating scale on } 24 \text { July. The percentages of leaf } \\
\text { surface that showed chlorosis and had two-spotted } \\
\text { spider mites on the underside of the damaged leaf area } \\
\text { were recorded. Horsfall-Barratt rating scale: } 1=0 \% \\
\text { leaf symptoms; } 2=0 \% \text { to } 3 \% \text { leaf symptoms; } 3=3 \% \text { to } \\
6 \% \text { leaf symptoms; } 4=6 \% \text { to } 12 \% \text { leaf symptoms; } 5= \\
12 \% \text { to } 25 \% \text { leaf symptoms; } 6=25 \% \text { to } 50 \% \text { leaf } \\
\text { symptoms; } 7=50 \% \text { to } 75 \% \text { leaf symptoms; } 8=75 \% \text { to } \\
88 \% \text { leaf symptoms; } 9=88 \% \text { to } 94 \% \text { leaf symptoms; } 10 \\
=94 \% \text { to } 97 \% \text { leaf symptoms; } 11=97 \% \text { to } 100 \% \text { leaf } \\
\text { symptoms; } 12=100 \% \text { leaf symptoms (Horsfall and } \\
\text { Barratt, } 1945 \text { ). } \\
\text { 'Means within a column followed by the same letter } \\
\text { were not significantly different according to Fisher's } \\
\text { least significant difference test }(\alpha=0.05 \text { ). }\end{array}$} \\
\hline
\end{tabular}

$\approx 6$ to 9 inches long, have thicker skin, and are dark green. The newly released parthenocarpic and gynoecious cultivars of this type, particularly Corinto, had high yield potential, outstanding fruit marketability, and developed less side shoot growth during these trials. It is a recommended cultivar for main season cucumber production under high-tunnel conditions.

Thin-skinned cucumbers are preferred by some consumers because they do not need to be peeled before eating. Beit alpha and mini, Dutch greenhouse, and Japanese cultivars meet this requirement. However, because the skins are thin, they are easily damaged by insect feeding or mechanical injury, particularly when the plants are grown in open hightunnel conditions. Preventing strong wind and insect pests from entering the high tunnel by installing insect netting on the sides and ends of the structures will likely improve the percentage of marketable fruit for these cultivars.

In this trial, Beit alpha and mini cucumbers were highly productive, especially when grown with intensive fertigation. In addition, their harvest began earlier. Most Beit alpha and mini cultivars should be harvested at a smaller size than slicer cucumbers. They may develop an off-taste if grown larger; therefore, timely harvest is essential for this type of cucumber. The Beit alpha and mini cucumbers evaluated during the study are suitable for growth under high-tunnel conditions. Among them, 'Socrates' had relatively higher marketable yield at two of the three locations.

Dutch greenhouse cucumbers can be easily differentiated from slicer cucumbers because of their large length:width ratio. They are individually wrapped and sell at premium prices. However, the yield potential might be lower for Dutch greenhouse cucumbers compared with other parthenocarpic cucumbers when grown in soil in open high-tunnel conditions, and they may form misshaped fruit if pollinated. Dutch greenhouse cucumbers may be more suitable for growth in enclosed greenhouse and hydroponic conditions than in open high-tunnel conditions.

Japanese cucumbers also have a large length:width ratio that differentiates them from slicer cucumbers. Japanese cucumbers are known for high fruit quality because of their higher flesh crispness compared with that of Beit alpha and Dutch greenhouse cucumbers (Shimomura et al., 2012). All Japanese cucumbers are monoecious plants that tend to develop more side shoots. During this trial, the cultivar Tasty Green was not suitable for protected cultural systems because of the low yield potential when it was grown using a singleleader system. In contrast, 'Tasty Jade' and 'Taurus' had yields comparable to those of the highest-yielding cultivars. During this trial, Japanese cultivars were more tolerant to twospotted spider mite damage, but 
Tasty Jade and Taurus were more susceptible to powdery mildew than many other cucumber cultivars. Japanese cultivars Tasty Jade and Taurus are suitable cultivars for high tunnels, especially when crispy cucumbers with a unique appearance are preferred by consumers.

\section{Literature cited}

Bogash, S., I. Gallo, and W. Brandenburg. 2014. High tunnel trellised cucumber variety trial: 2013.9 May 2019. <https:// extension.psu.edu/high-tunnel-trellisedcucumber-variety-trial-2013>.

Cantliffe, D.J., N.L. Shaw, and E. Jovicich. 2004. New vegetable crops for greenhouses in the southeastern United States. Acta Hort. 633:483-487.

Davidi, H. 2009. A history survey of cucumber breeding in Israel. Acta Hort. 830:33-36.

Egel, D.S., R. Foster, and E. Maynard. 2018. Midwest vegetable production guide for commercial growers 2019. Purdue Univ. ID-56.

Horsfall, J.G. and R.W. Barratt. 1945. An improved grading system for measuring plant diseases. Phytopathology 35:655 (abstr.).

Ingwell, L.L., S.L. Thompson, I. Kaplan, and R.E. Foster. 2016. High tunnels: Protection for rather than from insect pests? Pest Mgt. Sci. 73:2439-2446.

Ingwell, L.L., D.A. Avila-Ruiz, R. Foster, and I. Kaplan. 2018. Tailoring insect biocontrol for high tunnels. Biol. Control 123:76-86.

Knewtson, S.J.B., E.E. Carey, and M.B. Kirkham. 2010. Management practices of growers using high tunnels in the central great plains of the United States. HortTechnology 20:639-645.

Lamont, W.J., Jr., M.D. Orzolek, E.J. Holcomb, K. Demchak, E. Burkhart, L. White, and B. Dye. 2003. Production system for horticultural crops grown in the Penn State high tunnel. HortTechnology 13:358-362.
Lamont, W.J., Jr. 2009. Overview of the use of high tunnels worldwide. HortTechnology 19:25-29.

Maleknia, B., Y. Fathipour, and M. Soufbaf. 2016. How greenhouse cucumber cultivars affect population growth and two-sex life table parameters of Tetranychus urticae (Acari: Tetranychidae). Intl. J. Acarol. 42:70-78.

Morishita, M., K. Sugiyama, T. Saito, and Y. Sakata. 2003. Powdery mildew resistance in cucumber. Jpn. Agr. Res. Qrtly. 37:7-14.

Nennich, T.T. and S. Wold-Burkness. 2012. Minnesota high tunnel production manual for commercial growers. 2nd ed. 21 Feb. 2019. <https:// conservancy.umn.edu/handle/11299/ 197952>.

Papadopoulos, A.P. 1994. Growing greenhouse parthenocarpic cucumbers in soil and in soilless media Agr. Agri-Food Canada, Ottawa, ON, Canada.

Pierce, L.K. and T.C. Wehner. 1990. Review of genes and linkage groups in cucumber. HortScience 25:605-615.

Reid, J. 2015. Best management practices in high tunnel production: Cucumbers. 8 May 2019. <https://rvpadmin.cce. cornell.edu/uploads/doc_342.pdf $>$.

Sabelis, M.W. 1984. Biological control of two-spotted spider mites by Phytoseiulus persimilis on strawberries grown in walkin' plastic tunnels, and a simplified method of spider mite population assessment. Plant Pathol. 33:417-423.

Sakata, Y. and M. Sugiyama. 2002. Characteristics of Japanese cucurbits. Acta Hort. 588:195-199.

Sakata, Y., N. Kubo, M. Morishita, E. Kitadani, M. Sugiyama, and M. Hirai. 2006. QTL analysis of powdery mildew resistance in cucumber (Cucumis sativus L.). Theor. Appl. Genet. 112:243-250.

Sakata, Y., H. Horie, Y. Yoshioka, and M. Sugiyama. 2011. Fruit textures of Beit alpha, greenhouse, Japanese, pickling and slicer-type cucumbers. J. Jpn. Soc. Hort. Sci. 80:420-425.
Shaner, G. and R.E. Finney. 1977. The effect of nitrogen fertilization on the expression of slow-mildewing resistance in Knox wheat. Phytopathology 67:10511056.

Shaw, N.L. and D.J. Cantliffe. 2003. Hydroponically produced mini-cucumber with improved powdery mildew resistance. Proc. Florida State Hort. Soc. 116:58-62.

Shaw, N.L., D.J. Cantliffe, J.C. Rodriguez, S. Taylor, and D.M. Spencer. 2000. Beit alpha cucumber - an exciting new greenhouse crop. Proc. Florida State Hort. Soc. 113:247-253.

Shetty, N.V. and T.C. Wehner. 1998. Evaluation of oriental trellis cucumbers for production in North Carolina. HortScience 33:891-896.

Shimomura, K., Y. Yoshioka, and M. Sugiyama. 2012. Fruit texture variation among Beit alpha, European greenhouse and Japanese cucumbers (Cucumis sativus). Proc. X Eucarpia Mtg. Genet. Breeding Cucurbitaceae. p. 571-574.

Tatlioglu, T. 1993. Cucumber: Cucumis sativus L., p. 197-234. In: G. Kalloo and B.O. Bergh (eds.). Genetic improvement of vegetable crops. Pergamon Press, New York, NY.

U.S. Department of Agriculture. 1985. United States standards for grades of greenhouse cucumbers. 21 Feb. 2019. <https://www.ams.usda.gov/gradesstandards/greenhouse-cucumbers-gradesand-standards $>$.

Wallace, R.W., A.L. Wszelaki, C.A. Miles, J.S. Cowan, J. Martin, J. Roozen, B. Gundersen, and D.A. Inglis. 2012. Lettuce yield and quality when grown in high tunnel and open-field production systems under three diverse climates. HortTechnology 22:659-668.

War, A.R., M.G. Paulraj, T. Ahmad, A.A. Buhroo, B. Hussain, S. Ignacimuthu, and H.C. Sharma. 2012. Mechanisms of plant defense against insect herbivores. Plant Signal. Behav. 7:1306-1320. 